\title{
Framework to Measure Effectiveness of Teacher Professional Development
}

\author{
Sirikanya Srichom* Denchai Prabjandee Punwalai Kewara \\ Faculty of Education, Burapha University, Thailand
}

\begin{abstract}
This paper presents a framework developed to measure the effectiveness of teacher professional development programs. Adapted from Hunzicker's (2010) effective professional development, the framework consisted of five dimensions: supportive, job-embedded, instructionally focused, collaborative, and ongoing. The framework was then used to analyze the effectiveness of the teacher professional development programs in the Teacher Professional Development Coupons project in Thailand. The framework was used to analyze the programs qualitatively. The data revealed that most programs contain the elements of supportive, job-embedded, and instructionally focused; however, the elements of collaborative and ongoing were limited. Suggestions for future teacher professional development organizations are provided in terms of the quality of the programs, the monitoring system of the programs, and the program implementation.
\end{abstract}

Keywords: Effectiveness, Teacher professional development, framework, ongoing

DOI: $10.7176 / \mathrm{JEP} / 10-36-05$

Publication date: December $31^{\text {st }} 2019$

\section{Introduction}

Teacher professional development (TPD) is an important element for a successful teaching career because it provides an opportunity for teachers to develop professionally, which later leads to greater student achievement (European Commission, 2009; Eurydice, 2008). Thus, several countries around the world have provided various professional development for their teachers (European Commission, 2009; Eurydice, 2008). Similar to other countries, Thailand also provides various TPD programs for in-service teachers, especially those who teach English in the basic education level (K-12).

Recently, the educational reform movement in Thailand is setting a new image of offering teacher professional development, widely known as the "OBEC Training" or "Teacher Professional Development Coupons." In response to this policy, the Teacher Professional Development Institute (TPDI) was established as a comprehensive institution to manage, monitor, and maintain the quality of teacher professional development programs nationwide. The TPDI is responsible for screening and approving the TPD programs offered by educational institutions and other private sectors. According to this model, teachers can participate in any TPD program based on their interests from the central database. The registration system facilitates teachers to register for TPD programs via computer or smartphone at any time or place to respond to teachers' needs in all educational areas and reduce the disparity in professional development. The OBEC allocated 10,000 baht annually for each teacher to select professional development programs. The OBEC also has a policy to follow up and evaluate in order to verify if teachers implement the knowledge gained from the TPD.

The Teacher Professional Development Coupons project is still in its initial stage, which warrants the need to explore its effectiveness. An exploration of such project may yield insightful discoveries for the Ministry of Education in Thailand, which later may provide lessons learned for other researchers who attempt to implement a national-scale professional development project. Based on the implementation of the project,

there are many aspects to investigate as follows. First, since there were many educational institutions and other private sectors submitted the TPD to be approved, whether the TPDI was able to control the effectiveness of TPD remained unanswered. Second, it is unknown whether or not the TPD program cover all teachers' need based on teacher's ID plan. Last, it is useful to explore whether if it was worth with a huge budget (approximately one thousand four hundred million baht) in terms of apply any the new knowledge in the classroom.

In fact, the TPDI has attempted to evaluate the quality of TPD programs submitted to be approved, by using 15 requirements indicating that the approved curriculum must have the following requirements, such as: 1) clear objectives, 2) clear target teachers, 3) constructive alignment between content and objective, 4) balance between lecture and practice, 5) adequate details of activities, etc. (TPDI, 2017). However, by using the 15 requirements as criteria that response to the Ministry of Education's policy, the quality of TPD programs remains unknown. Therefore, this study attempts to develop a framework to measure the effectiveness of the TPD programs offered in the TPDI project.

\section{The present study}

This study attempts to answer the following research question: To what extent do the TPD programs for Thai 
English teachers offered in the Teacher Professional Development Coupons project contain the effectiveness of teacher professional development?

\subsection{Theoretical Framework}

The theoretical perspective of effectiveness for teacher professional development serves as a philosophical stance to identify the TPD program effectiveness. The term effectiveness was an operationalized definition from Hunzicker (2010) consisting of five dimensions.

Table 1 The Definition of the Effectiveness of the Teacher Professional Development

\begin{tabular}{|c|c|c|}
\hline Dimensions & Original Definition & Operationalized Definition \\
\hline Supportive & $\begin{array}{l}\text { Effective professional development is supportive } \\
\text { because it considers the needs of individual teachers, } \\
\text { schools and districts. The teachers feel supported } \\
\text { because the professional development is tailored by } \\
\text { school, classroom, and grade level, engaging } \\
\text { individuals from all levels; therefore, they are more } \\
\text { willing to learn and improve teaching practice. }\end{array}$ & $\begin{array}{l}\text { TPD addresses the authentic needs of } \\
\text { teachers, responds to the MOE } \\
\text { policy, is part of the qualification } \\
\text { process in upgrading their teaching } \\
\text { career, accommodates individual } \\
\text { learning styles, and allows teachers } \\
\text { to make choices. }\end{array}$ \\
\hline Job-embedded & $\begin{array}{l}\text { Effective professional development for teachers is } \\
\text { job-embedded, which makes it both relevant and } \\
\text { authentic. Job-embedded professional development } \\
\text { engages teachers in learning through their daily } \\
\text { activities and responsibilities, and requires that they } \\
\text { take time to consider possibilities, try out new ideas, } \\
\text { and analyze the effectiveness of their actions. }\end{array}$ & $\begin{array}{l}\text { TPD connects to teachers' daily } \\
\text { responsibilities both academically } \\
\text { and administratively, and requires } \\
\text { teachers to implement their } \\
\text { knowledge in their classrooms. }\end{array}$ \\
\hline $\begin{array}{c}\text { Instructionally } \\
\text {-focused }\end{array}$ & $\begin{array}{l}\text { Effective professional development for teachers is } \\
\text { instructionally-focused, which involves the study and } \\
\text { application of content and pedagogy with emphasis } \\
\text { on student learning outcomes. Instructionally-focused } \\
\text { professional development is effective because } \\
\text { teachers consider the emphasis on subject area } \\
\text { content and pedagogy relevant and authentic to their } \\
\text { daily responsibilities. }\end{array}$ & $\begin{array}{l}\text { TPD addresses concern in English } \\
\text { classrooms, emphasizes methods, } \\
\text { activities, techniques of ELT and } \\
\text { applications. TPD supports teachers } \\
\text { to increase students' achievement in } \\
\text { English classrooms, and encourages } \\
\text { teachers to create right conceptions } \\
\text { in learning sustainable English. }\end{array}$ \\
\hline Dimensions & Original Definition & Operationalized Definition \\
\hline Collaborative & $\begin{array}{l}\text { Effective professional development for teachers is } \\
\text { collaborative because it engages teachers in both } \\
\text { active and interactive learning. Professional } \\
\text { development is active when teachers engage } \\
\text { physically, cognitively and emotionally through } \\
\text { activities such as problem-solving, discussion, } \\
\text { simulations, role-play and application. It is } \\
\text { interactive when teachers value opportunities to learn } \\
\text { from and with one another around common goals } \\
\text { such as instructional planning, analyzing student } \\
\text { work and peer observations. Teachers feel that } \\
\text { providing built-in support for collaborative } \\
\text { professional development is more enjoyable than } \\
\text { working alone. }\end{array}$ & $\begin{array}{l}\text { TPD engages teachers physically, } \\
\text { cognitively, emotionally, and } \\
\text { socially, TPD engages teachers to } \\
\text { share their ideas, work together } \\
\text { toward common goals, and give } \\
\text { feedback to each other. }\end{array}$ \\
\hline Ongoing & $\begin{array}{l}\text { Effective professional development for teachers is } \\
\text { ongoing, which involves a combination of contact } \\
\text { hours, duration, and coherence. Professional } \\
\text { development is most effective when teachers have } \\
\text { multiple opportunities to interact with information } \\
\text { and ideas over several months. When such } \\
\text { opportunities are related to each other as well as to } \\
\text { school goals or state learning standards, teachers are } \\
\text { able to see the "big picture" that strengthens their } \\
\text { motivation and commitment to the ongoing learning } \\
\text { process. }\end{array}$ & $\begin{array}{l}\text { TPD extends teachers' knowledge } \\
\text { and experience gained from the PD } \\
\text { to other teachers, TPD encourages } \\
\text { teachers to contact in groups to } \\
\text { further applications, offers consulting } \\
\text { sessions after the PD, and provides } \\
\text { opportunities for follow-up } \\
\text { improvement. }\end{array}$ \\
\hline
\end{tabular}




\subsection{Accessing the TPD Programs}

In this study, the TPD programs were under the OBEC training project, launched by the Ministry of Education, Thailand. The OBEC training project allowed educational institutions such as schools, universities, government educational service area offices, provincial education offices, and private corporations (companies, partnerships, associations, or foundations) to offer courses by submitting a curriculum to be approved by the TPDI, which stipulated 15 course requirements (TPDI, 2017). All approved courses were listed online via the TPDI website for teachers to shop courses based on their interests. Each teacher was given ten thousand baht for their courses. After the screening process, there were 1,460 approved courses. Out of this number, 111 courses were related to the teaching and learning of the English language. The 111 courses were examined in this study.

Out of 111 courses, only 26 courses were accessible through the TPDI website. There were several reasons for such limited number of accessible courses. Firstly, it was the first year of this project, the management was not really well systematic, so not all approved programs were listed in the TPDI website. Secondly, some courses were deleted from the website after they were approved and no explanations were provided by the TPDI of why the details of the courses were not listed in the website. Thirdly, it was not easy to access the TPDI website because the server was busy owing to many teachers visited the website at the same time trying to shop their courses. The 26 TPD related English programs were produced by Educational Institutions and Private Corporate (see Table 2).

Table 2 TPD Programs Related to Teaching and Learning of English

\begin{tabular}{lcc}
\hline \multicolumn{1}{c}{ Organization } & Accessible Curriculum & Cannot Access \\
\hline Educational Institutions & 9 & 58 \\
Private Corporate & 17 & 27 \\
\hline Total & 26 & 85 \\
\hline
\end{tabular}

As shown in Table 2, there were 26 TPD programs. Nine programs were created by an education institution, and 17 programs were produced by a private corporate. Unfortunately, the other 85 TPD programs were not found: 58 programs were from Educational Institutions and 27 programs by a private corporation.

When considered the purposes of the 26 TPD programs based on development area, there were classified into four areas: language skills, pedagogy, assessment, and online TPD program (see Table 3).

Table 3 TPD programs classified by the purposes

\begin{tabular}{lll}
\hline \multicolumn{1}{c}{ Development area } & Curriculums & Number \\
\hline Language skills & A, C, D, H, J, N, Q, R, and U & 9 \\
Pedagogies & B, I, K, L, O, P, S, T, V, W, and X & 11 \\
Assessment & E, F, and G & 3 \\
Online TPD program & M, Y, and Z & 3 \\
\hline
\end{tabular}

As shown in Table 3, there were four development areas for teacher who participated the TPD program. Language skills combined with the A, C, D, H, J, N, Q, R, and U programs. Pedagogies or teaching English theories included the B, I, K, L, O, P, S, T, V, W, and X programs. There were three programs aimed to develop teacher's for assessment themselves: the E, F, and G programs. The last area was the online TPD program: the M, $\mathrm{Y}$ and $\mathrm{Z}$ programs.

\subsection{Trustworthiness of the Analysis}

To maximize the trustworthiness of analyzing the TPD programs, an interrater technique was used. I analyzed the TPD programs by using an effective professional development framework with transcribing and searching for themes. I read the TPD curriculum, then did the coding, categorized, and found the themes. After that, I repeated the cycle process until the data was saturated and reached a consensus.

\section{Findings}

\subsection{Supportive}

Overall, the findings revealed that all 26 TPD programs consisted of the supportive dimension. The dominate reason is the goal of the Teacher Professional Development Coupons covers characteristics of support in the effective professional development framework: 1) addressed the authentic needs of teachers, 2) respond to the MOE policy, 3) is a part of qualification process in upgrading position in teaching career, 4) accommodated individual learning styles, and 5) allows teachers to make choices.

Specifically, the data from the interview teacher who enrolled the TPD program is more evidence to confirm that the 26 TPD programs offered in the OBEC training project contained the supportive principle: the $\boldsymbol{I}$ program. The purposes of the $\boldsymbol{I}$ program combined with reviewing and developing English teacher skills needed focus on using ICT and media to develop Thai students as an ASEAN community to survive in the $21^{\text {st }}$ century. The $\boldsymbol{I}$ program conducted TPD activities that fostered teacher who enrolled the programs reached the goals. For example: demonstrate how to use ICT, advance searching for education, download-upload realia media from YouTube: English conversation, song, cartoon, movie for education, practice teaching by implementing what 
they have learned, observed, reflected with colleagues and followed up online.

Anong, a Thai English teacher who enrolled in the $\boldsymbol{I}$ program, recommended the useful and responsiveness of teachers' needs. She briefly described the $I$ program that:

"The I program is a TPD program that focus on using ICT to teach English. I have learned a lot from this program both to improve my ICT skills: presenting with advance power point program, searching useful information for educate myself and preparing the lesson for my students, and improve my teaching English skills with ICT: download documents, and English experiences on YouTube for education. It was active TPD program, all participants." (Anong, December 8, 2017)

Based on the interview, the $I$ program responded to Anong's need: ICT and teaching skills. Skill is one part of teacher's need: knowledge, skill, and teacher identity for developing as a professional teacher.

In conclusion, the 26 TPD programs offered in the OBEC training project definitely contained the supportive principle since the programs were produced to address the authentic needs of teachers, respond to the MOE policy, be a part of the qualification process in upgrading position in teaching career, accommodate individual learning styles, and allow teacher to make choices.

\subsection{Job-embedded}

The next element, job-embedded, aimed to assess whether the TPD programs connected to teachers' daily responsibilities both academically and administratively, and TPD required teachers to implement their knowledge in their classrooms. Hence, I addressed job-embedded in the TPD program's in two aspects: connected to teachers' daily responsibilities both academically and administratively and required teachers to implement their knowledge in their classrooms.

The first aspect displayed that the TPD programs connected to teachers' daily responsibilities both academically and administratively. To identify that the TPD programs connected to teachers' daily responsibilities both academically and administratively consisted of eight themes: 1) enhancing communicative English skills for teachers, 2) improving English skills for a variety of groups, 3) providing knowledge of teaching English, 4) designing assessment activities, 5) development of ICT skills and technology in learning and teaching, 6) use English in various situations, 7) planning and preparing lesson plans, and 8) fostering a good attitude toward communicative English for everyday life and career.

- Enhancing communicative English skills for general teachers and teachers who got an A1 or A2 CEFR placement test, included preparing the teachers' capacity in basic communicative English skills: brush up on the knowledge about words and sentence structures, introducing, requesting, inviting, apologizing, and English for presentation. In addition, there were not only intensive training programs but also there were online courses and live chat: the A, B, C, Y, and Z program

- Improving English skills for variety groups responding to current policy for example: enable NonEnglish Majored teachers' ability in planning lessons and employing teaching techniques in their teaching, enhance both kindergarten teachers and administrators' capacity for communicative English teaching skills, provide business communication English for an international level, offer teaching management in the $21^{\text {st }}$, century, and improving English based on the students' interests, attitudes and individually: the $\mathrm{H}, \mathrm{K}, \mathrm{L}$, and etc.

- Providing knowledge of teaching English combined with terms and concepts of teaching English, English for young learners, phonetics principles, creative criticism skill, learning management, Brain Base Learning Approach, Content and Language Integrated Learning (CLIL) integrated with innovation Lesson study theory, step in using online social media work, and for kindergarten teachers: the U, X, and etc.

- Designing assessment activities: choosing assessment activities, assessing young learners, and evaluation and assessment based on theory: the F program.

- Teacher professional development program is job-embedded because it developed ICT skills and technology in learning and teaching by enhancing teachers' ability in selecting and using effective instructional media and teaching methodology: the I program.

- Use English in various situations as an important tool for communication focusing on exchanging of Thai cultures and identities with the global society by enhancing the ability of the students and teachers to be a professional English-speaking master of ceremonies (MC): the D program.

- Planning and preparing lesson plans included identifying and selecting lesson aims, identifying the different components of a lesson plan, planning an individual lesson or sequence of lessons, and design lesson plans with ICT: the I program.

- Foster good attitudes toward communicative English for everyday life and career

In addition, the second aspect of the TPD programs was job-embedded because the programs required teachers to implement their knowledge in their classrooms. The analyzed data were presented in two parts: apply 
in teaching and learning, and conduct lesson plan.

The TPD programs' objective mostly indicated how to apply teaching and learning in the participants' classroom: apply existed instructional media in English skills, apply the curriculum in their own classroom, apply the approach in their learning management, understood how to apply "teach less, learn more", apply instructional media in conducting learning activities, and employing teaching techniques in their teaching activities.

Moreover, when exploring the TPD program in deep detail it was found that the TPD program addressed how the program process responded to teacher's job-embedded, for example, the $\mathbf{X}$ program was the good example of teachers' daily responsibilities both academically and administratively, and how teacher implement their knowledge in their classrooms as follows.

"The main goal of this approach is developing student thinking skill with the 4 STEPs instruction: STEP 1: Presentation of open-ended problem; STEP 2: Students learn by themselves; STEP 3: Discussion and extension of the concept; STEP 4: Teacher sums up students' concept. At the same time, the teacher works with a team weekly as professional learning community: PLC in order to plan together, observe together, and reflect together as Triple-Co: Collaborative Plan, Collaborative Do, and Collaborative Reflection." (Introduction of the X program)

The TPD's program aims to present new approaches that enhance student's thinking skills and clearly describes the instructional process. It supports teacher implementation in the classroom. Interestingly, teacher have a team to design lesson plans, observe classrooms while implementing in the classroom, and get feedback from observers.

In conclusion, the TPD coupons mostly were job-embedded since the analyzing of description, introduction, objective, and expect results of the TPD coupons indicated that they connected to teachers' daily responsibilities both academically and administratively, and TPD required teachers to implement their knowledge in their classrooms.

\subsection{Instructionally-Focused}

Next was the instructionally-focused element, the analysis purposed to evaluated whether the TPD coupons: 1) addressed concerns in English classrooms, 2) emphasized on methods, activities, techniques of ELT and applications, 3) support teachers to increase students' achievement, and 4) encouraged teachers to create the right conceptions in learning sustainable English. The findings are presented as below.

First, the findings overall revealed that most of the TPD coupons addressed concerns in English classrooms. The evidence displayed how the TPD coupons addressed concerns in English classrooms because firstly, the programs enhanced English teachers in English learning and teaching skills, terms and concepts, and promote using English as medium of instruction. Second, the TPD coupons did not only focus on communicating English skills but also provided one of learning strands of the Foreign Language Learning area: Language and relationship with community and the world. Third, the TPD coupons supported the participants to design lesson plan packages for each grade level of students based on the indicators, planning lessons, and assessment based on teaching techniques or approach for example: Brain Based Learning Approach, Instructional media, Active learning, Integrated activities of English for communication, Content Based, Communicative Language Teaching approach, Content and Language Integrated Learning, techniques for promoting thinking process, and Lesson study theory. Fourth, the TPD coupons promote learning and teaching to respond to the Ministry of Education's policy: the educational revolution in the $21^{\text {st }}$ century by enhancing English teaching skills, English language teaching using the CEFR framework, ICT skills, and CLT approach. Finally, the TPD coupons enhance knowledge management (KM) about teaching and learning management.

The target participants of TPD coupons included Thai English teachers who got A1-A2 from the CEFR placement test, Non-English Majored Teachers, Kindergarten Teachers, Administrators, and Thai English teachers who teach young learners.

However, there were five out of twenty-six TPD coupons that did not address the concerns in English classrooms since the programs focused on only developing English proficiency for Thai English teachers, administrators, Non-English Majored Teachers, and Kindergarten Teachers to be confident in using English and be a better model for their students. The $\mathbf{J}$ program was a good example as it was described in content of the program as follows:

"The J program was advanced English skills: professional writing and presentation combined with business presentation and writing." (Content of the J program)

Second, the TPD coupons were instructional focused because they emphasized on methods, activities, techniques of ELT and applications. I mentioned three themes: methods or approaches, activities, and techniques and applications of ELT which were found in the description, introduction, objective, and expected results of the TPD coupons as below.

There were several methods or approaches found in the TPD coupons, for example: Present Practice 
Reinforcement Production method (PPRP), natural approach, Presentation, Practice and Production (PPP), TaskBased learning (TBL), Total Physical Response (TPR), the lexical approach, Grammar-translation, test-teach-test, guided discovery, Brain Base Learning approach, Communicative Language Teaching (CLT), Best Practice, Sufficient English for integrated studies innovation, ICT in English Language Teaching (ELT), Teach less, Learn more approach, Self-learning virtual technology, Learner-centered approach, Instructional media, Content and Language Integrated Learning (CLIL), and Innovation Lesson study theory.

Next was activities found in the TPD coupons that made them instructional focused. The activities included instructional four skills activities, international recreation activities, activities as a master of ceremony, introductory activities: warmers and lead-ins and common ways of presenting language, selecting appropriate assessment activities to build into lessons, activities for fostering good English attitude, English Professional Learning Community (PLC) activity, Leaner-centered activities, and Open class activity.

The last was techniques of ELT and application found in the TPD coupons combined with fun and motivational teaching techniques, techniques for promoting an integrated thinking process, techniques for learning management by individual interest, techniques of using English instructional media effectively, and practicing sessions for different teaching techniques.

Same as the first theme, the second theme "emphasized on methods, activities, techniques of ELT and applications", there were three out of twenty-six TPD coupons: the M, Q, and Y programs did not refer to or emphasize on methods, activities, techniques of ELT and applications. Since the TPD coupons focused on only developing English proficiency for Thai English teachers, administrators, Non-English Majored Teachers, and Kindergarten Teachers to be confidence in using English and be a better model for their students.

Third, the TPD coupons included instructional focused because they support teachers to increase students' achievement. There were only ten TPD coupons indicated to support teachers increasing students' achievement in English classroom: the B, C, D, H, I, O, P, S, T, and X programs. The rest not really found or never mention about the success of the students. Because the goal of those programs focused on teacher's knowledge of the terms and concepts common in English language teaching, and other programs focused teachers' English proficiency.

The students' achievement in English classroom were indicated by testing, correctly, fluency, and good attitude. The examples of testing displayed by the students get better grades, pass specified standard measurement, and raise the O-NET exam results. The correct samples were of students reading and speaking long and complete sentences correctly, students obtain larger lexicon that they can use different sentence structures in English communication, and focusing on students' excellence in English. The fluency shows students have better listening, speaking, reading, and writing skills, students obtained better English skills and use English in everyday life, and students can be a professional English speaker master of ceremonies. In addition, students have good attitudes towards learning communicative English skills which foster their determination and enthusiasm in continuous learning, students obtain high order thinking: analysis, creativity, and good attitudes toward learning.

The $\mathbf{T}$ program is a good example as it indicates the objectives and expected results of the program as follows:

“The T programs' objectives were to enhance: 1) the capacity in English language teaching and learning management of Prathomsuksa 6 teachers, 2) the teachers' understanding of the O-NET exam and effective adaptation in real classrooms, and 3) the teachers' understanding of using English instructional media effectively" (Objectives of the $\boldsymbol{T}$ program) which coherent with the expected results of the T program: 1) the teachers obtain understanding about teaching and learning management which will raise the O-NET Exam results, and 2) the students obtain understanding and skills in the O-NET Exam." (Expected results of the $\mathbf{T}$ program)

Fourth, the TPD coupons included instructional focused because they encouraged teachers to create the right conceptions in learning sustainable English. The analyzed results figured three groups of teacher encouragements to create the right conceptions: teachers were provided the knowledge in English learning and teaching, teachers were updated understanding to the Ministry of Education's policy: skills for the $21^{\text {st }}$ century, and teachers have positive attitude toward English, realize the importance of using English in classroom by themselves and finally be better role models for students instead of depending on foreign teachers.

The $\mathbf{L}$ program was the good example as it was indicated in the introduction of the program as follows:

"One effective way in the foundation of taking English into classrooms which is a sustainable investment is to enhance local kindergarten in-service teachers' capacity communicative English teaching skills without relying on outsource personnel or foreign teachers." (Introduction of the $\mathbf{L}$ program)

In conclusion, the TPD coupons mostly were instructional focused since the analyzing of description, introduction, objective, and expect results of the TPD coupons indicated that most of the TPD coupons addressed concerns in English classroom, most of the TPD coupons emphasized on methods, activities, techniques of ELT and applications, there were ten TPD coupons indicated to support teacher increasing students' achievement in 
English classroom, and most of the TPD coupons encouraged teachers to create right conceptions in learning sustainable English.

\subsection{Collaborative}

Last but not least, the collaborative element, the analysis aimed to determine whether the TPD coupons engaged teachers to: 1) be physical, cognitive, emotional, and social, 2) share their ideas, 3) work together toward common goals, and 4) give feedback to each other. The analyzed results found mostly that the TPD coupons engaged teachers physically, cognitively, emotionally, and socially. While the rest was not found, more details are addressed.

Overall, the findings revealed that the TPD coupons consisted of collaboration by engaging teachers physically, cognitively, emotionally, and socially with six different ways: the participants have the opportunity to practice after they were presented new knowledge, conduct a micro-teaching, design a 1-hour lesson plan and lesson plan packages, create English professional learning community (PLC), and online courses (group discussion, one-on-one live chat). However, there were six TPD coupons that engaged only cognitively because the TPD coupons provided only the knowledge to participants.

The TPD coupons were not really collaborative because there were few activities that engaged teachers to share their ideas. However, there were example of engaging: provide opportunity for teacher to share, interview, reflection session, micro-teaching, open class activity, and PLC. There were six TPD coupons that engaged teachers to share their ideas through social networks: the A, C, M, R, Y, and Z. The Z program is a good example of an effective professional development program which included the collaborative element in the expected results:

"To provide opportunity for trainees to share and exchange knowledge and experiences, set up networks among school teachers and build collaboration between educational institutes. " (Objective of the Z program)

Additionally, the TPD coupons rarely show collaboration in engaging teachers to work together toward common goals. In other words, the TPD coupons mostly promote teachers to work individually to learn the new knowledge and implement it in the classroom. The exception was the R program, which promoted English professional learning community (PLC), and the X program that supported the innovation Lesson study theory, open class activity, and PLC which needed teamwork.

The last indicator to describe the effectiveness of professional development in collaborative was the TPD program engaged teacher to give feedback to each other. There were only four TPD programs included this element: the $\mathrm{C}, \mathrm{R}, \mathrm{U}$, and $\mathrm{X}$ programs though do micro-teaching which teachers get and give feedback to each other, reflection session, Innovation Lesson study theory, open class activity, PLC, coaching, mentoring, and supervision.

In conclusion, the TPD coupons mostly were collaborative on engaging teachers physically, cognitively, emotionally, and socially with six different ways. The analyzing of the description, introduction, objective, and expected results of the TPD coupons indicated that most of the TPD coupons rarely engaged the participants to share their ideas, to work together toward common goals, nor to give feedback to each other.

\subsection{Ongoing}

Finally, the ongoing element, the analysis aimed to determine whether the TPD programs offered by the TPDI extended the knowledge and experience gained from the TPD to other teachers, encouraged teachers to contact in group to further applications, offered consulting sessions after the TPD program, and provided opportunities for follow-up improvement.

Overall, the findings revealed that the TPD coupons rarely consisted of all the ongoing indicators. The first indicator, there were only the $\mathrm{D}$ and $\mathrm{Z}$ programs which extended the knowledge and experience gained from the TPD to other teachers. The D program described the expected results that "cascade knowledge and experience gained from the workshop to other teachers in the school such as setting up a club of professional English master of ceremony or developing a course for English master of ceremony." This was the same as the D program, the $\mathrm{Z}$ program indicated the expected results that "Trainees can also pass on the knowledge from the workshop to other colleagues."

The second indicator, there were six TPD programs that encouraged teachers to contact in group to further applications by: 1) creating social media networks: Facebook, Line, and Instagram to share their work experience, 2) doing English Professional Learning Community (PLC), and 3) Open class activity. The third indicator, there were three TPD programs: L, T, and Z that offered consulting sessions after the PD by consulting service, consulting online community, and Facebook or Line for mentoring and coaching, respectively. The fourth indicator, there were six TPD programs: the C, H, O, P, T, X, and Z that provided opportunities for followup improvement by following on workshop, Innovation Lesson study theory, Open class activity, PLC, coaching, mentoring, supervision, and social media network follow on.

In conclusion, the TPD coupons rarely included ongoing. The samples of ongoing activities found 
combined with social media network to share their work experience, Professional Leaning Community, and Innovation Lesson study theory.

\section{Conclusion}

In conclusion, by measuring the effectiveness of teacher professional development program with the framework, the data revealed that most TPD coupons contain the elements of supportive, job-embedded, and instructionally focused; however, the elements of collaborative and ongoing were limited.

In general, an effective professional development program combines supportive, job-embedded, instructionally focused, collaborative, and ongoing (AFT, 2008; Cooper, 2004; Hunzicker, 2010). Theoretical implication here informed that whenever you create a professional development program, all elements should be included in the curriculum. All parts are important for the effectiveness of the professional development program.

The finding in the study did not support the above recommendation, most professional development programs produced without the "ongoing" element. The educational institutions (schools and universities), government services (educational service area offices, provincial education offices), and corporations (companies, partnerships, associations), and foundations which offer their courses as teacher professional development program may need to rethink their curriculum.

In addition, the TPDI might include "ongoing" as criteria for improving teacher professional development programs. This practice may increase the effectiveness of teacher professional development coupons and improve quality.

Another pivotal practice for the TPDI in which response to the teacher professional development coupons, it would be more practical if there was more budgeted to go through "on going" as same as pay for the teacher professional development program

\section{References}

Borko H 2004, "Professional development and teacher learning: Mapping the terrain", Educational Research, 33(8), 3, Available: https://doi.org/10.3102/0013189X033008003

Carroll C, Patterson M, Wood S, Booth A, Rick J, \& Balain S 2007, "A conceptual framework for implementation fidelity", Implementation Science, doi: 10.1186/1748-5908-2-40.

Cooper, D. (2004). Professional development: An effective research-based model. New York: Houghton Mifflin.

Dane A, \& Schneider B 1998, "Program integrity in primary and early secondary prevention: Are implementation effects out of control?", Clin Psychol Rev. vol. 18, no.1, pp.23-45.

Darling-Hammond, L., Hyler, M. E., \& Garder, M. (2017). Effect teacher professional development, Palo Alto: Learning policy institute.

Darrow, C. L. (2013). "The effectiveness and precision of intervention fidelity measures in preschool intervention research. Early Education \& Development”, 24(8), 1137-1160.

European Commission. (2009). Key data on education in Europe. Luxembourg: Office for Official Publications of the European Communities.

Eurydice. (2008). Levels of autonomy and responsibilities of teachers in Europe. Brussels: Eurydice.

Hunzicker, J. L. (2010). Characteristics of effective professional development: A checklist. Available: http://www.files.eric.gov/fulltext/ED510366.pdf (July 2, 2010)

IASA. (1996). High-quality professional development supports education reform. Available: www.ed.gov/pubs/IASA/newsletters/profdev/hqprodev.html (November 12, 1996)

O’Donnell, C. (2008). Defining, conceptualizing, and measuring fidelity of implementation and its

relationship to outcomes in K-12 curriculum intervention research. Review of Educational Research, 78(1), 3384.

Teacher Professional Development Institute [TPDI]. (2017). The curriculum certification criteria. Available: http://site.ksp.or.th/home.php?site=tpdi

The American Federation of Teachers [AFT]. (2008). Principles for professional development. Available: www.aft.org/sites/default/files/pd_principles_2008.pdf. 